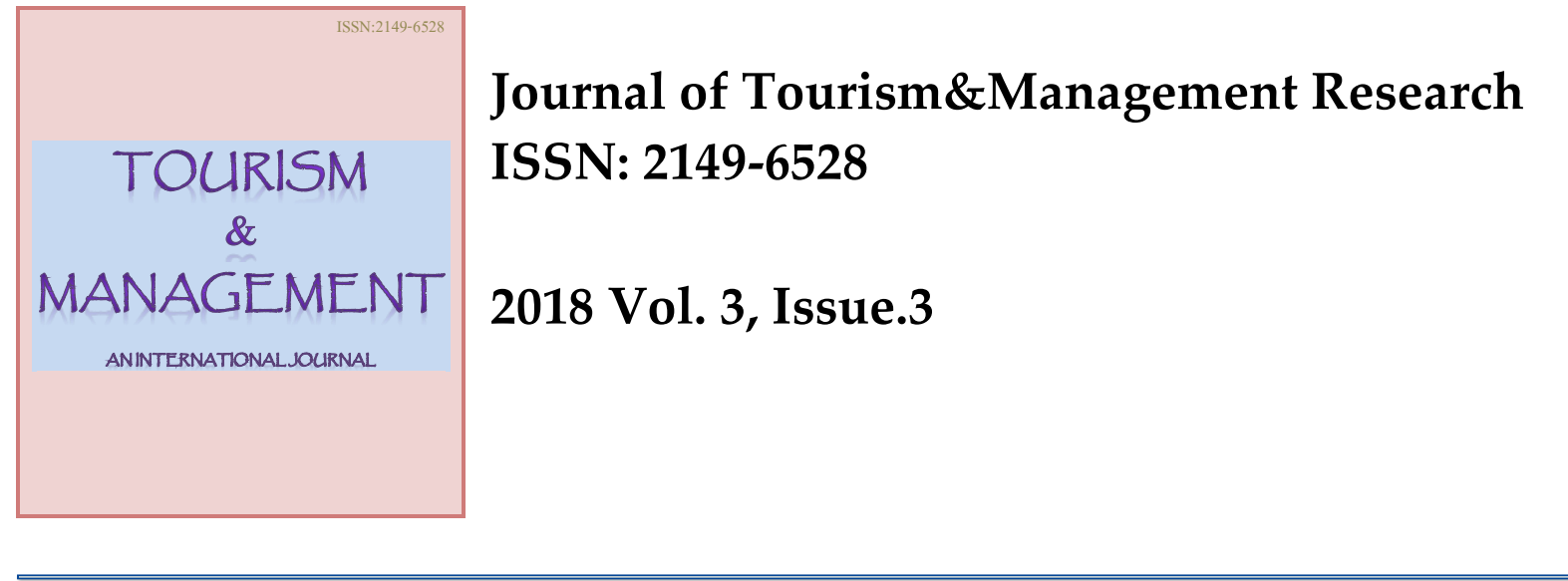

\title{
The Impact of Tourism Development on Greenwich Community in the Post-Olympic Games Era
}

\begin{abstract}
The purpose of this study is to analyze the impact from tourism development on the Greenwich community in the Post-Olympic Games era, as such the social, environmental and economic impact on local community in the Post-Olympic Games era. The paper was developed first review pre-existing literature on tourism, Olympic tourism, mega-event tourism, sustainable tourism and past academic research on the impacts from tourism. By using convenient and judgmental sampling technique, the data was collected from 100 respondents and analyzed using descriptive statisctics. Importantly, the results revealed that stakeholders would like to see more inward investment from the private sector to capitalize on the modernization and infrastructure improvements that have taken place in the area. Local businesses would like more foreign tourists to visit Greenwich in particular, rather than Central London. The local community remains supportive of tourism development, but do urgently seek a strategy implementation that can improve their standards of living and make the most of the Olympic infrastructure for the forthcoming.
\end{abstract}

Keywords: Economic, Environmental, Greenwich community, Post-Olympic games, Social, Tourism development.

JEL Classifications: R58, Z32, Z39.

Submitted: 05/10/2018; Accepted:27/11/2018

Md Yusuf Hossein Khan. Assistant Professor. (Corresponding Author). College of Tourism and Hospitality Management, International University of Business Agriculture and Technology, Dhaka 1230, Bangladesh; Ph.D. Researcher in Tourism, University of Algarve, Faro, Portugal.

Email: ysf.khn86@gmail.com

Sheikh Md. Abdul Hakeem. Ph.D Student. Portsmouth Business School, Portsmouth University, Richmond Building, Portland St, Portsmouth P01 3DE, UK

Email: skhakeem@hotmail.co.uk

Afzal Hossain. MBA Student. Comilla University, Shalmanpur 3506, Comilla, Bangladesh.

Email: hafzal.mktcou@gmail.com 


\section{Introduction}

The requirement to practice sports mega events to drive long-term progressive plans has placed the theory of event legacy within the actual event planning (Weed and Bull (2004). In this regard, Brazil had the distinctive opportunity of hosting two sports mega events in a row the 2014 FIFA World Cup and the 2016 Olympic and Paralympics Games. According to Curi (2013), the Pan American Games of 2007 in Rio de Janeiro is what opened the doors for Rio to host the 2016 Olympic Games. The Pan American Games were extremely regarded by the international sports federations. While this was the first ever games hosted in South America, it was regarded surely and many young players within Brazil were able to watch them live, which aided in their Olympic education. The outcomes designated prospective positive and negative social effects of Olympic Games 2016. In order to maximize the potential positive factor, there requirements to be ample management and public policies that facilitate the population to practice sports. The undesirable social effects included very high costs with no benefits for the population, misuse of public money, and lack of accountability for the money invested into this event. These results may add to the planning of mega events in order to generate well public policies of sport and recreation, so that persons can appreciate these benefits while diminishing the adverse factors (Robinson, et al., 2017). The influence of the electronic media to beam these events to numerous portions of the world creates the Olympics a potent channel for showcasing the host country to the whole world. Several host nations have taken benefit of such an opportunity such as in 1964, Japan used the Olympics as a tool to reestablish its image that was in tatters following the role it played in World War II. The 24th Olympiad held in Seoul in 1988, became the impetus for the cessation of autocratic rule in South Korea (Walkosz and Foss, 2009). The study have provided evidence that the Olympics affords the host country an opportunity to show its military, economic, political, and cultural importance in a favorable way Many studies (Dong et al., 2005). The Olympics held in South Korea, Spain, Australia and Greece showed that the host countries became more visible in the international media, and the tone of the reports about them became more positive over time. Stories about the host countries published after the games depicted them as less threatening to the global status quo and to common values (Wang and Wang, 2007).

In 2012, The Olympic Games were held across London and the UK, including venues in Greenwich. Before bidding to host for the Games, the residents and local community of Greenwich were given the arguments for the benefits that could be gained from hosting such an event. Tourism is already an important industry, worth $£ 114 \mathrm{bn}$ to the UK economy and predicted to grow to $£ 188$ bn in the next ten years (Buccellato et al. 2010). So, there is an economic need to improve and develop tourism in Greenwich. As the Olympics has just ended and there is an issue of how best to create a long lasting legacy from the investment and spending that has gone into the Olympics project. The summer Olympics, measured the largest sports event in the world being held every four years and attracts hundreds of millions of spectators. To the host country, it proposals a number of benefits, including drumming the world's interest in its cultural wealth, providing job opportunities for its people, attracting revenues from tourism, and opening friendly families with the worldwide community. This study focuses on a significant Olympics function that of increasing the image of the host country (Preuss, 2004).

The Olympics were very successful and there is an opportunity to make to capitalize on the successful image of London and the Greenwich area in particular. Greenwich is also a World Heritage site, has its own dedicated Tourist Information Centre which has won a silver award in a recent Visit England Awards for Excellence. So, it is an opportunity to review and assess current strategies that have been successful in developing tourism and also review which strategies have not worked so well. Greenwich has had large amounts of investment from both the private and public sector into its tourist sites, its maritime sites, shopping facilities, hospitality and entertainment facilities (such as the $\mathrm{O} 2$ Arena) so it is an opportunity 
to calculate the economic return on investment into the area and predict the potential for future profits from investing in the area.

Against this backdrop, the current paper assesses the real impact from tourism on Greenwich and its local community. It attempts to assess how the community has been affected by the development and whether the gains from tourism are worth the costs faced by stakeholders. The broad objective of the research is to analyze the impact from tourism development on the Greenwich community in the Post-Olympic Games era. There are some specific objectives, which are as follows;

a) Analyze how the current tourism strategy incorporates the effects of Post-Olympics, and assess the strengths and weaknesses in this strategy.

b) Analyze how the borough will overcome tourism challenges and maximize the benefits from the Olympics.

c) Assess the role of other organizations and government bodies to promote tourism in Greenwich, on a local, national and international level, and how London will support the borough to carry the Olympic legacy in Greenwich.

d) Analyse the impact of tourism development on Greenwich and its community.

e) Analyse the roles of stakeholders involved with tourism development in Greenwich and offer strategies for improving tourism development in Greenwich.

\section{Literature Review}

\subsection{Tourism Industry}

The Austrian economist Schaller was one of the first to formally define tourism in 1910, describing the concept as one that involves the total activity of many different operators motivated by economic reasons and involving the movement, entry or stay inside and outside certain regions, cities or countries. Travel \& Tourism continued to show its resilience in 2016, contributing direct GDP growth of 3.1\% and supporting 6 million net additional jobs in the sector. In total, Travel \& Tourism generated US\$7.6 trillion (10.2\% of global GDP) and 292 million jobs in 2016, equivalent to 1 in 10 jobs in the global economy (WTTC, 2017). The sector accounted for $6.6 \%$ of total global exports and almost $30 \%$ of total global service exports. The Tourism Industry is defined as a mass of organizations from different sectors supplying those activities termed tourism (Cooper, 2011). Tourism is the short-term movement of people to places they do not normally reside or work. Tourism is an activity that involves a wide range of stakeholders, such as individuals, businesses and organizations to deliver a service (Leiper, 2004).

\subsection{Mega Event Tourism}

Dansero and Puttili, (2010) establish how mega event locations, after investment and infrastructure developments are able to benefit in the future by being a location that is able to hold more events and commercial opportunities (e.g. exhibitions, music and sporting events) after the initial event. This is able to provide a long lasting source of income and stream of regular tourism if managed correctly. Another study showed that this is analyzed in 'Megaevents tourism legacies: the case of the Torino 2006 Winter Olympic Games - a territorialisation approach'. It studies the improvement of facilities for hospitality and accommodation, better infrastructures, better training for people in the tourism business, and improvement in international image of tourist destinations. These improvements in the locations where mega events are held are also able to benefit locals with improved transport connections, more services and amenities for the domestic population to utilize as well as tourists. It also provides an environment for local businesses to develop and capitalize on the economic benefits from tourism (e.g. more income, more sales, and more employment). Olympic tourism is a relatively new term, mostly formalized (Weed, 2008). Most academic study of such event tourism has been considered under the 'Mega-Event Tourism' 
classification. Roche (2000) defines mega-sporting events as "large-scale cultural (including commercial and sporting) events which have a dramatic character, mass popular appeal and international significance." Mega-event tourism is tourist activity related to participating at that event or activity inspired by the event.

\subsection{Olympic Tourism}

The Olympic Games held in London, and at sites in Greenwich, in 2012 are an example of a supply-side activity that brought tourists to the area. According to Weed (2008), Olympic tourism is defined as being "tourism behavior that is motivated or generated by Olympicrelated activities" and Olympic-related activities can involve sports participation, tourism with sporting content, sports event tourism, sports training or generic tourism all set in the pre-Games, during the Olympic Games and the Post-Olympic Games period and also another exploration stresses the need for businesses to develop relationships before and during the Olympic Games in order to maximize its leverage capabilities in the post-Games period. In addition stresses the role of media involvement and public exposure of the destinations to enhance the image of locations such as London positively, so that the destinations become a 'consideration set' of possible locations for future trips. Leveraging is different to a simple impact analysis of the Games and is a tactic to capitalize on opportunities and be pro-active in its strategic focus. Olympic tourism flows may be positive, negative or have neutral effects (Weed, 2008). Research showed that positive media coverage of Calgary during the 1988 Winter Olympics improved the attractiveness of Calgary as destination (Ritchie, 1991). Chalip (2004) stresses the importance of leveraging on the Olympic Games in order to develop tourism and maximize the positive effects of the event.

\subsection{Sustainable Tourism}

Minnaert (2011) researched that some arguments may be valid, such as the excess spending on the Olympics in Beijing 2008 and overspend in which is why consideration should be given to the sustainability of the project. This also extends to the sustainability of tourism development which is one of the intended outcomes of the Olympic Games for London 2012. Bramwell and Lane (1993) recognized the potential for tourism to negatively impact the environment and social aspects of a destination. The London 2012 Games were organized with the intention of being environmentally friendly and this approach was taken in the infrastructure and development of projects for tourism shown by the Green Tourism for London Scheme launched in 2007. This involved a green purchasing guide and co-operation with stakeholders offering tourist services during and after the Olympics in London with a sustainable agenda. Bruntland (1987) stresses the need to balance the social, economic and environmental needs when managing and marketing tourist destinations. The study presents mixed results for sustainable tourism figures during and after Olympics with the Seoul 1988 visitor numbers exceeding expectations whereas the figures for the Los Angeles Games in 1984 failed to meet predicted figures. Another research argues that long term management and planning of the event must be implemented to fully leverage the benefits of sustained tourism from mega events such as the Olympic Games (Chalip, 2002).

\subsection{Tourism Development, Strategy and Planning}

Successful tourism strategy and planning is the key for implementing sustainable tourism after an event such as the Olympic Games. Morse (2001) exemplifies the approach incorporated for the Sydney 2000 Olympic Games. The Australian Tourist Commission (ATC) was involved as part of the Olympic planning committee and started tourism strategy planning in 1992, some eight years before the start of the event. The ATC decided to work with other stakeholders and organized the Olympic Games Business Unit (OGBU) in 1995 with the function of identifying opportunities for tourism development. The OGBU 
formalized its goals as being measurable, achievable and realistic. Its main objectives involved the increase of visitors to Australia, increasing the amount of income generated from tourism to Australia, increasing the geographic dispersal of tourists to Australia and not just to Sydney after the Games and increasing its market share of tourist visits from countries it was actively marketing in. The key goal was to promote the tourism industry, make it more sustainable and provide jobs and wealth for the country. The OGBU achieved these goals with heavy media promotion and cooperation with the Olympic partners such as advertisers who featured Australia and Sydney's geography and tourist facilities and also stressed the importance of tourism strategy implementation lasting long after the event finished in 2000 . Critics of the model argue that it is outdated (Leiper, 2004) and suggestions that more stages should be included in the model (Agarwal, 2006). There is potential for a stage of reorientation at a destination after a series of stagnation where the site management may be able to reinvent and refresh the offerings at the location leading to success and rejuvenation, or the onset of decline where the reorientation of offerings fails to excite the visitor.

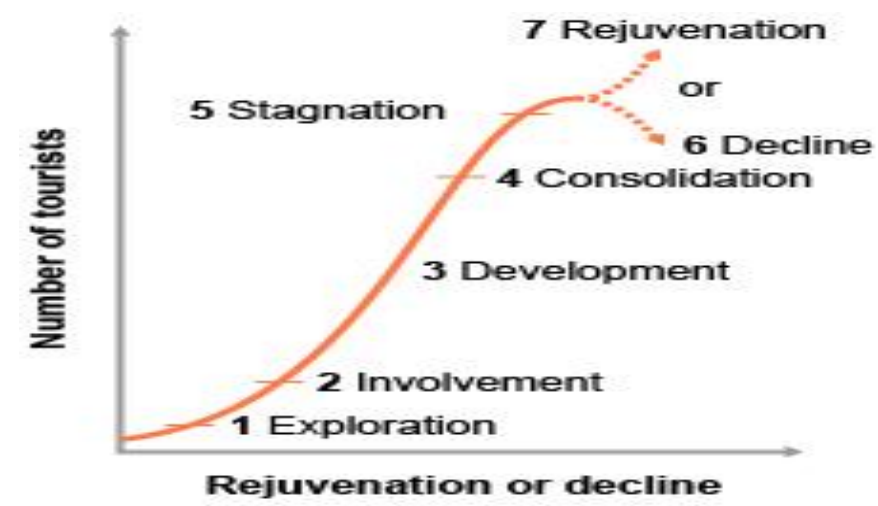

Figure 1. The Tourism Area Life Cycle (Butler, 1980).

\subsection{Tourism Challenges and Benefits}

Tourism to Australia as a consequence of the Sydney 2000 Olympic Games is estimated to add over a $\$ 2.9$ billion to national income figures. This positive impact is reinforced by studies (Hyun, 1990) where an extra 640,000 visitors travelled to Seoul after the 1998 Olympics. Kang and Perdue (1994) estimate as much as 1 million extra visitors came to Seoul as a consequence of the successful Games events held there. Chalip (2002) writes extensively upon the tourism opportunities that can arise from staging the Olympic Games in a destination. Another study that points at the large public investment in staging the Sydney Games in 2000 estimated at being $\$ 2.3$ billion whilst private investment was estimated to be at $\$ 1.2$ billion and Moreover another research that argues that this mixture of investment is spent on staging the Olympic Games in the expectation of a positive return on investment and GDP for the host nation leaving a legacy that is founded on the tourism impact from the Olympic Games. The positive combinations of these effects are suggested to improve tourism and future trade levels, with greater investment into the area and future marketing opportunities. There is also a sports legacy left with more people participating in sports and motivated by the possibility in competing at Olympic sites. The study presents that such positive outcomes are dependent on a successful staging and well financially managed Olympic Games. The suggestion that the prominence of sporting legacy is the main outcome from holding the Olympic Games is also downplayed. Evidence from Barcelona after 1992 shows that under utilization of the diving and baseball facilities meant the demolition of such venues in the City and likewise estimates a positive impact for tourism levels after the Olympics with the Tourism Forecasting Council in Australia estimating that there will be an extra 1.6 million visitors to Australia in the period up to 2004. 


\subsection{Tourism Impact on the Local Community}

The impact of tourism can have positive or negative affects which will influence policy and planning for tourism. Examples of positive effects from tourism development include economic outcomes such as more labor being employed and adding to the Gross Domestic Output (GDP) of a nation. Negative effects from tourism include over-dependency on tourism for economic growth or inflationary pressures on land in an economy (Kammas, 1993). This viewpoint raises the importance of the local community on embracing tourism opportunities for future advantages, particularly in the aftermath of a major sporting event. Hritz and Ross (2010) investigated the perceived impacts of sports tourism in an urban community context to assess the advantages and disadvantages from sports tourism. Another study showed that argue that sports tourism has been an increasing trend, and a segment that has lacked formal analysis from most tourism studies. The tourism industry is in essence, a hospitality and service industry, typical of a guest and host relationship (Smith, 1992). This is a claim reinforced by Murphy (1985) describing tourism as a social cultural event for both the host and guest, meaning that the both parties will be affected by the participation of the other. Gibson (2006) suggests the importance of future study into the social impact from tourism on a host community. Hritz and Ross (2010) recognized the growing nature of sports tourism and support for event tourism in Indianapolis and constructed a study based upon the perceived impacts on a social, environmental and economic viewpoint. Research questions were created to analyze residents' opinions and their views on future sporting events tourism in the community. On the other hand, Hritz and Ross (2010) also studied for a possible difference in opinions shared by participants based on their age, gender, period of residence and education levels. In a study of social cultural impacts from tourism on the hosts in a British coastal resort by Brunt and Courtney (1999), it was established that the extent of impact on the host community depends on the individual's relationship with the tourism industry. Attitudes towards the impact from tourism were not homogenous and differed between residents in the community. There is a critique of suitable participants for the study as it is suggested that attitudes and opinions differ between the general community and their occupations (Krippendorf, 1987). Andriotis and Vaughan (2003) suggest that those residents who also work in an occupation related to tourism in the local community are more informed and able to express opinions on the impact of visitors to their communities. Vogt and Jun (2004) claim the general population may not understand the nature of tourism to their community and the services and behaviors by visitors to their area so are not always able to express an informed value judgment.

\section{Methodology}

This study applies random sampling technique since this study aims to investigate the perceptions of local residents towards the impact of tourism development on Greenwich Community in the Post-Olympic Games era by reaching a large proportion of the population in order to gain more accurate, reliable and objective data. In total, 100 questionnaires were aimed to collect from residents from different occupational groups. The research has been conducted in Greenwich during April 2017. Prior to the distribution of main questionnaires, in order to test for any necessary revision of the research content, the questionnaire was pilot tested with 15 local residents from different areas of the city. As a result of the pilot test, no reason was found to change the survey instrument.

The participants were provided the questionnaires together with an explanation and a guarantee that their confidentiality and anonymity would be assured throughout the whole research process. The research team tried to collect data on a face to face basis and, so as to get a higher response rate. However, due to the financial and time limitations, this was not possible all the time and thus social media channels were alternatively used in this study. As a 
result, most of the questionnaires were conducted on a face to face basis with the willing respondents. In this research, the total number of usable questionnaires was 100.

The survey instrument comprises of mainly two sections that measure the impacts of tourism development and demographic profile of residents respectively. The first section consists of 17 questions which were divided into three sections such as social, environmental, and economic impacts. Section Two comprised five items consisting of age, gender, occupation, education qualification, and monthly income of residents in Greenwich/UK.

The Statistical Package for Social Sciences version 22 was used to analyze the data. As for statistical techniques, first reliability (Cronbach's alpha) value and validity tests were conducted. And respectively, the exploratory factor analysis was performed in order to provide support for issues of dimensionality, as well as convergent and discriminate validity. Next, mean score descriptive analysis was employed to observe average responses of the respondents who participate in this survey.

\section{Results}

\subsection{Descriptive Statistics}

Table 1 demonstrated that half of the respondents were middle-aged people (30-43 years; $52.0 \%)$. The majority of respondents in this study were male (65.0\%). Majority of the respondents were businessman $(40.0 \%)$. Majority of the people were graduate $(45.0 \%)$ and finally, most of the respondents (45.0\%) had income level between 1200-2000 GBP in this study.

Table 1: The demographic profile of respondents.

\begin{tabular}{|l|l|l|}
\hline Demographic variable & Frequency & Percentage \\
\hline Age & & \\
17-30 Years & 25 & 25 \\
30-43 Years & 52 & 52 \\
$45-58$ Years & 15 & 15 \\
58 Years + & 8 & 8 \\
& & \\
\hline Gender & 65 & 65 \\
Male & 35 & 35 \\
Female & & \\
& & \\
Occupation & 30 & 30 \\
In service & 40 & 40 \\
Business & 20 & 20 \\
Students & 10 & 10 \\
Others & 15 & \\
\hline Education Qualification & 25 & 15 \\
SSC & 45 & 25 \\
HSC & 10 & 10 \\
Graduate & 5 & 5 \\
Post-graduate & & \\
Others & 30 & 30 \\
& 45 & 45 \\
\hline Monthly Income & 15 & 15 \\
Below 1200 & 10 & 10 \\
1200-2000 & & \\
2000-2800 & & \\
2800 above & & \\
\hline
\end{tabular}




\subsection{Psychometric Properties of the Measure}

In order to test construct reliability, this study used Cronbach's alpha coefficient to examine internal consistency (Nunnally, 1978). As shown in table 2, the overall reliability for the scales exceeded the acceptable cut-off value of 0.70 as suggested by Nunnally (1978), indicating that items are free from random error and internal consistency is adequate (Fornell \& Larcker, 1981). In order to see whether the distribution of the values was adequate for conducting analysis, the Kaiser-Meyer-Olkin (KMO) measure of sampling adequacy was used and the constructs exceeded the threshold value of 0.50 as suggested by Field (2000). In addition, Bartlett's test of sphericity measure indicated that the multivariate normality of the set of distributions was normal for the all constructs, showing a significant value, $\mathrm{p}=0.000$ (< $0.05)$.

\subsection{Mean Scores}

Table 2 reveals that out of six propositions on Social aspects, two propositions mean score is 4 or above but less than 5 on likert- 5 point scale for propositions (Olympics and the events that take place, encourage a variety of cultural activities). Therefore, most of the respondents have agreed significantly influence on Greenwich Community in the Post-Olympic Games era. For remaining four propositions on social aspects, two propositions mean score is 3 or above but less than 4 on likert-5 point scale for propositions (Meeting tourists from other regions is a valuable experience, positive impacts on the cultural identity of Greenwich) mean score is 3 or above but less than 4. So, respondents have somewhat agreed to influence on Greenwich Community in the Post-Olympic Games era. For remaining two propositions (increase crime, fund spent on Tourism in Greenwich is a waste of money) mean score is 2 or above but less than 3. As a result, respondents have disagreed to influence on Greenwich Community in the Post-Olympic Games era.

Table 2: Social aspects impact on the Greenwich community.

\begin{tabular}{|l|c|c|}
\hline \multicolumn{1}{|c|}{ Social Aspects } & Mean & S.D \\
\hline Olympic tourism has increased crime in Greenwich & 2.3400 & 1.61012 \\
\hline $\begin{array}{l}\text { The local community has suffered from living in Greenwich due to the } \\
\text { Olympics and the events that take place here }\end{array}$ & 4.5200 & 0.89223 \\
\hline $\begin{array}{l}\text { Tourism to Greenwich has encouraged a variety of cultural activities by the } \\
\text { local residents }\end{array}$ & 4.6700 & 0.71751 \\
\hline $\begin{array}{l}\text { Meeting tourists from other regions is a valuable experience } \\
\text { to understand their culture and society }\end{array}$ & 3.7900 & 1.79132 \\
\hline $\begin{array}{l}\text { Olympic tourism has resulted in positive impacts on the cultural identity of } \\
\text { Greenwich }\end{array}$ & 3.6500 & 1.78631 \\
\hline $\begin{array}{l}\text { Funds spent on Tourism in Greenwich is a waste of money that could be } \\
\text { used better to improve Greenwich }\end{array}$ & 2.7100 & 1.89542 \\
\hline
\end{tabular}

Note: SD:Standard Deviation.

Table 3 exhibits that out of six propositions on Environmental aspects, four propositions mean score is 4 or above but less than 5 on likert-5 point scale for propositions (provide more parks and other recreational areas, provide an incentive for the restoration of historical buildings and the conservation of natural resources, traffic congestion, noise and pollution, establish the natural environment). Therefore, most of the respondents have agreed significantly influence on Greenwich Community in the Post-Olympic Games era. For remaining two propositions on social aspects, one proposition mean score is 3 or above but less than 4 on likert-5 point scale for propositions (Roads and public facilities are kept at a high standard). Thus, respondents have somewhat agreed to influence on Greenwich Community in the Post-Olympic Games era. For remaining one proposition (good for the 
safety and welfare for the natural wildlife in the area) mean score is 2 or above but less than 3 . As a result, respondents have disagreed to influence on Greenwich Community in the PostOlympic Games era.

Table 3: Environmental aspects impact on the Greenwich community.

\begin{tabular}{|l|c|c|}
\hline \multicolumn{1}{|c|}{ Environmental Aspects } & Mean & S.D \\
\hline Tourism provides more parks and other recreational areas & 4.2800 & 0.88095 \\
\hline Roads and public facilities are kept at a high standard due to sport tourism & 3.7100 & 1.71357 \\
\hline $\begin{array}{l}\text { Tourism has provided an incentive for the restoration of historical } \\
\text { buildings and the conservation of natural resources }\end{array}$ & 4.1200 & 0.89129 \\
\hline Tourism has resulted in traffic congestion, noise and pollution & 4.7500 & 0.82611 \\
\hline $\begin{array}{l}\text { Construction of sport tourist facilities has destroyed the natural } \\
\text { environment }\end{array}$ & 4.8900 & 0.91369 \\
\hline $\begin{array}{l}\text { Tourism development has been good for the safety and welfare for the } \\
\text { natural wildlife in the area }\end{array}$ & 2.9200 & 1.72331 \\
\hline
\end{tabular}

Note: SD:Standard Deviation.

Table 4 demonstrates that out of five propositions on Economic aspects, four propositions mean score is 4 or above but less than 5 on likert-5 point scale for propositions (Create more jobs in Greenwich, Give a boost to the local economy and local businesses, improve standard of living). So, most of the respondents have agreed significantly influence on Greenwich Community in the Post-Olympic Games era. For remaining two propositions (Increase of the price of goods and services, the cost of tourism development is too much). Thus, respondents have somewhat agreed to influence on Greenwich Community in the Post-Olympic Games era.

Table 4: Economic aspects impact on the Greenwich community.

\begin{tabular}{|l|c|c|}
\hline \multicolumn{1}{|c|}{ Economic Aspects } & Mean & S.D \\
\hline Tourism has created more jobs in Greenwich & 4.5700 & 0.70071 \\
\hline Tourism has given a boost to the local economy and local businesses & 4.9000 & .99739 \\
\hline My standard of living has improved because of tourism in Greenwich & 4.7500 & 0.80915 \\
\hline $\begin{array}{l}\text { The price of goods and services has increased because of tourism in } \\
\text { Greenwich }\end{array}$ & 3.3300 & 1.71567 \\
\hline The cost of tourism development is too much for Greenwich & 3.3400 & 1.87161 \\
\hline
\end{tabular}

Note: SD:Standard Deviation.

\section{Conclusion, Implications and Limitations}

This study assessed the perceived impact from tourism on the Greenwich Community, in the post period after the London 2012 Olympic Games where the gains from holding the megaevent would have a positive impact on the local community. Generally tourism in Greenwich is supported by local stakeholders and raises a significant amount of revenue for the local economy. However it is clear that the community is affected socially, environmetally as well as economically by tourism which requires those responsible for tourism development in Greenwich to consider the needs and extent to which tourism is encouraged in the area. Opinions do differ amongst stakeholders but largely local residents do feel part of the community and feel the need for tourism in Greenwich. There is evidence of the social exchange theory in practice in Greenwich where local residents have accommodated tourism 
development, but they feel disappointed by the lack of support from planners in helping their needs and developing other parts of the local economy. The statistics clearly show that tourism is a positive economic contributor to Greenwich and the wider community but residents do not feel their standards of living have increased due to tourism. Local stakeholders would like to see more improvements in parking and local transport as they feel the area is heavily congested as a consequence of the activities in Greenwich. There is also concern at the environmental and sustainability of further tourism development with concern for local wildlife. Socially tourism and leisure opportunities in Greenwich have added greatly to the local community who are culturally richer and feel more positive about the image of Greenwich following their experiences following the staging of the London 2012 Games. Local stakeholders are feeling the effects from tourism and do not feel local tourism officials are doing enough to develop the industry in the future. They are also unclear about the future path or strategy which means tourism officials need to engage more with the local community to remind them of the positive benefits that arise from tourism. A lack of support from the local community will damage tourism development (Perdue et al. 1990) so it is important the local authorities promote Greenwich in the media and through other modern methods (e.g. Social Media). Morse (2001) showed the model for local tourism development following the staging of the Olympic Games in Sydney by the ATC implementing a plan for before and after the Olympics. Official Olympic Legacy reports do not suggest that the stated expectations of a legacy in Greenwich will come to fruition with residents acknowledging a disappointing outcome in terms of economic opportunities, status and more attractions. Whilst the local community is supportive of the financial management of tourism development in Greenwich, they are concerned that as a location Greenwich has not capitalised on the postOlympic benefits and is danger of tourism levels returning to normal (Ritchie et Al. 1991). The report concludes that the local authority and tourism body needs to continue to promote tourism to Greenwich, and build relationships that will attract private investment and create new opportunities for the local community. There has been an uncoordinated response to managing tourism development in the post-Olympic era and local stakeholders would like to see more done to maximize the benefits from the investment and development of the area following the successes of the recent past. The local community remains supportive of tourism development but do urgently seek a strategy implementation that can improve their standards of living and make the most of the Olympic infrastructure for the future.

The local area has gained considerably from the improvements in transport, infrastructure, new services, hospitality and construction that arise from staging the Olympic Games. However in the aftermath of staging the Olympic Games, there is a concern from those interviewed that the local authorities and those bodies responsible for tourism development are not capitalizing on the potential benefits from the Games, by 'leveraging' the staging of the event for their advantage (Chalip, 2004). There is a need for more relationship building between businesses and other organizations that could bring in more visitors (Weed 2008), such as staging more sporting event, which is distinctly lacking from research. There should be urgency from tourism organizers to capitalize on the benefits from the previous few years' investment by staging more events, promoting more heavily and connecting with stakeholders (Dansero et al. 2010; Roche 2000). Stakeholders would like to see more inward investment from the private sector to capitalize on the modernization and infrastructure improvements that have taken place in the area. Tourism seems to be Greenwich's largest industry and more private investment in the area can create other industries which would make the local community less reliant on tourism as a source of income. The area has a growing reputation for education which can be expanded and other business development is welcome to balance out the seasonal effect from tourism income. Local businesses would like more foreign tourists to visit Greenwich in particular, rather than Central London so more can be done to boost the image and prominence of Greenwich as an area. A post-Olympic advertising and 
media campaign with partners should be considered to achieve this story and keep positive stories of Greenwich in the news. The area can build upon its rich cultural event profile as its strong point but critically more is needed to develop a sporting legacy which was promised before the Olympics. More sporting events and participation is needed in the area as an infrastructure for mega-events already exists, but is being underutilized. There is also confusion from stakeholders as to who is responsible for organizing and managing the post Olympic tourism development strategy for the area. The organization needs to be managed better between the central government, the Mayor of London's office and the local area council. A joint partnership between these organizations to build on the Olympic legacy in Greenwich needs to produce a future strategy for achieving the recommendations proposed in this investigation and this strategy needs to be effectively communicated to the local community as they are currently unsure as to what the future holds for development in Greenwich.

The paper is restricted in inside Greenwich, London, UK duration in Olympic Games only and the result may not be applicable to other places. This data may not be the true representative of Greenwich community respondents. The result is obtained based on the respondents' opinion. So, there is a chance of respondent's bias. The sample size is only 100. The study conducted in tourism development (social, environmental and economic) only as independent variable. Therefore, there may be some other variables which may influence on Greenwich Community in the Post-Olympic Games era.

\section{References}

Agarwal, S. (2006). Coastal Resort Restructuring and the TALC. In R.W. Butler Ed.

Bramwell, B. \& Lane, B. (1993). Sustainable tourism: an evolving global approach. Journal of Sustainable Tourism, 1 (1), 1-5.

Brundtland, T., (1987). Brundtland report. In: (WCED) World Commission on Environment and Development, Our Common Future, Oxford: UK, Oxford University Press.

Brunt, P., \& Courtney, P. (1999). Host perceptions of sociocultural impacts, Annals of Tourism Research, 26, 494-515.

Buccellato, T., Webber, D., White, S., Ritchie, F. \& Begum, S., (2010). The economic impact of tourism across regions and nations of the UK. Economic and Labour Market Review, $4(5), 44-50$.

Butler, R.W., (1980). The concept of the tourist area life-cycle of evolution: implications for management of resources. Canadian Geographer, 24 (1), 5-12.

Chalip, L., (2002). Using the Olympics to optimise tourism benefits. Centre d'Estudis Olimpics. Universidade Autonoma de Barcelona.

Chalip, L., (2004). Beyond impact: a general model for sport event leverage. In Ritchie, B., Adair, D.2004. Sports tourism: Interrelationships, impacts and issues (pp. 226-252). England: Channel View Publications.

Cooper, C, (2011), Essentials of Tourism, Harlow : Financial Times Prentice Hall

Creswell, J.W. \& Plano Clark, V.L. (2007). Designing and conducting mixed methods research. Thousand Oaks, CA: Sage Publications.

Curi, M. (2013). The dispute for the legacy of sports mega events in Brazil. Horizontes Antropológicos, Porto Alegre, ano 19(40), 65-88.

Dansero, E. and Puttili, M., (2010). Mega-events tourism legacies: the case of the Torino 2006 Winter Olympic Games - a territorialisation approach, Leisure Studies, 29 (3), 321

Dong, X., Li, Q., Shi, Z., Yu, Y., Chen, G. \& Ma, Z. (2005). Beijing Olympic Games and building national image: Subject analysis of the foreign media's reports on four Olympic holders. China Soft Science, 2, 1-9. 
Field, A. (2000). Discovering Statistics using SPSS for Windows. London, Thousand Oaks, New Delhi: Sage publications.

Hritz, N. \& Ross, C., (2010). The Perceived Impacts of Sport Tourism: An Urban Host Community Perspective. Journal of Sports Management, 24,119-138.

Hyun, J. (1990). The Impact of the 1988 Seoul Olympics on Inbound Tourism to Korea, Study on Tourism, 235-245.

Kammas, M. (1993). The positive and negative effects of tourism development in Cyprus., Cyprus Review, 5 (1), 70-89.

Kang, Y.S. \& Perdue, R., (1994). Long-term Impacts of a Mega-event on International Tourism to the Host Country: A Conceptual Model and the Case of the 1988 Seoul Olympics, in M. Uysal (ed.), Global Tourism Behavior, International Business Press, 205-225.

Krippendorf, J. (1987). The holiday makers. Understanding the impact of leisure and travel. Oxford, UK: Butterworth Heinemann.

Leiper, N. (2004). Tourism Management (3rd Ed.), Malaysia: Pearson Education Australia.

Minnaert, L. (2010). An Olympic legacy for all? The non-infrastructural outcomes of the Olympic Games for socially excluded groups (Atlanta 1996-Beijing 2008), In Tourism Management, 33(2), 361-370.

Morse, J. (2001). The Sydney 2000 Olympic Games: How the Australian Tourist Commission leveraged The Games for Tourism. Journal of Vacation Marketing, 7, 101-110.

Murphy, P.E., (1985). Tourism: A community approach. New York: Methuen.

Nunnally, J.C. (1978). Psychometric theory (2nd Ed.). New York: McGraw-Hill Book Company.

Perdue, R.R., Long, P.T. and Allen, L., (1990). Resident support for tourism development. Annals of Tourism Research, 17, 586-599.

Preuss, H. (2004). The economics of staging the Olympics: A comparison of the Games, 1972-2008. Northampton, MA: Edward Elgar

Ritchie, J. R. B. \& Smith, B. H., (1991). The impact of a mega-event on host region awareness: A longitudinal study. Journal of Travel Research, 30, 3-10.

Robinson, T.M., Cinthia Silva, L., Garnett, R. \& Patreze, N.S. (2017). Rio 2016 Olympic Games and the Social Impacts of Mega events: A Qualitative Study. Licere, Belo Horizonte, 20(3), 348-366.

Roche, M. (2000). Mega-events and modernity: Olympics and expos in the growth of global culture, London: Routledge.

Smith, V. (1992). Hosts and guests revisited. The American Behavioral Scientist, 36,187-199.

Veal, A.J. (2006). Research Methods for Leisure \& Tourism: A Practical Guide, Third Edition, Harlow, Financial Times/ Prentice Hall.

Vogt, C.A. \& Jun, S.H., (2004). Residents' attitudes toward tourist market segments and tourism development in Valdez, Alaska: A comparison of residents' perceptions of tourist impact on the economy and quality of life. Proceedings from the 2004 Northwest. Recreation Research Symposium, Newtown Square, Pennsylvania, pp.404411.

Walkosz, B. J. \& Foss, S. K. (2008). China and the 2008 Olympics: The construction of a national image. Retrieved February 4, 2009, from the All Academic Inc. web site: http://www.allacademic.com/meta/p172488_index.html.

Wang, H. (2003). National image building and Chinese foreign policy. China: An International Journal, 1(1), 46-72.

Wang, K. M. \& Wang, X. (2007). National image and Olympic coverage. Paper presented at the annual convention of the Association for Education in Journalism and Mass Communication, Washington, D.C.

Weed, M. (2008). Olympic tourism. Amsterdam; London: Butterworth-Heinemann. 
Weed, M. \& Bull, C. (2004). Sports tourism: Participants, policy, and providers. Oxford: Elsevier/Butterworth.

World Travel and Tourism Council. (2017). The economic impact of travel \& tourism report.

\section{Author Biography}

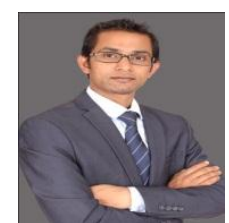

Md Yusuf Hossein Khan is currently working is an Assistant Professor at the College of Tourism and Hospitality Management (CTHM) of IUBAT-International University of Business Agriculture and Technology, Dhaka, Bangladesh. He is also a Ph.D Researcher at the faculty of Economics at University of Algarve, Portugal. Yusuf $\mathrm{H}$ Khan has completed his MSc in International Tourism Management from the Cardiff Metropolitan University, UK, and MBA International from the Anglia Ruskin University, UK. Besides, being a member of Research Centre for Spatial and Organizational Dynamics (CIEO - Portugal) he is also serving several International Journal as an Editor and reviewer. Yusuf H Khan is an expert in curriculum design and currently is an active member for CTHM curriculum task force team of IUBAT. His current research interests are in particular, Safety and Risk in Tourism, Travelers loyalty, Tourism destination image and development, Global leadership in Tourism and Hospitality, Human resources practices, Business entrepreneurship. He has good number of publications on these area.

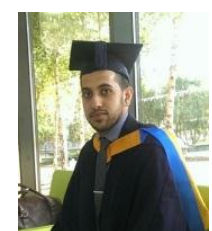

Sheikh Md. Abdul Hakeem is a Ph.D. Student at the Portsmouth Business School of Portsmouth University, England. He has Completed his MBA from Anglia Ruskin University, UK and BSc in Tourism and Hospitality Management from University of Sunderland, UK. His current research interests are Urban Tourism, Community involvement in Tourism, Tourism Marketing.

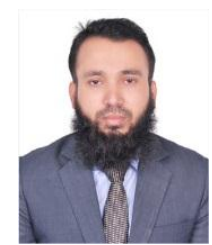

Afzal Hossain is a MBA student of Marketing at the Comilla University of Comilla, Bangladesh. He has also completed his BBA in Marketing from the same university. Afzal Hossain holds 1 year experience of working at a project under the University Grants Commission of Bangladesh. His current research interest area are Environmental Marketing, Business Development, Female Entrepreneurship, Community based Tourism 